\title{
Distribution and ecotoxicology of bioavailable metals and As in surface sediments of Paraguaçu estuary, Todos os Santos Bay, Brazil
}

\author{
Taís de S. Pereira ${ }^{a}$, Ícaro T.A. Moreira ${ }^{\mathrm{a}, \mathrm{b}, *}$, Olívia M.C. de Oliveira ${ }^{\mathrm{a}, \mathrm{d}}$, Mariana C. Rios ${ }^{\mathrm{a}}$, Wilton A.C.S. Filho ${ }^{\mathrm{c}}$, \\ Marcos de Almeida ${ }^{a}$, Gilson Correia de Carvalho ${ }^{a}$ \\ ${ }^{a}$ Núcleo de Estudos Ambientais, Instituto de Geociências, Universidade Federal da Bahia (UFBA), Campus de Ondina, 40170-290 Salvador, BA, Brazil \\ ${ }^{\mathrm{b}}$ Mestrado em Energia, Escola de Engenharia e TI, Universidade Salvador (UNIFACS), Salvador, BA, Brazil \\ ${ }^{c}$ Laboratório de Estudos dos Oceanos e Clima, Instituto de Oceanografia, Universidade Federal do Rio Grande (FURG), Carreiros, 96203-900 Rio Grande, RS, Brazil \\ ${ }^{\mathrm{d}}$ Instituto de Geociências, Departamento de Geofisica Aplicada, Universidade Federal da Bahia (UFBA), Campus de Ondina, 40170-290 Salvador, BA, Brazil
}

\section{A R T I C L E I N F O}

\section{Article history:}

Received 23 February 2015

Revised 11 July 2015

Accepted 13 July 2015

Available online 17 July 2015

\section{Keywords:}

Bioavailability

Metals

Sediments

Estuaries

\begin{abstract}
A B S T R A C T
Surface sediments collected in the intertidal zone of Paraguaçu estuary in July, 2013, were analyzed for organic matter, nitrogen, phosphorus, grain size fractions and partial concentrations of 16 metals. The USEPA 3051A method and ICP-OES and CV-AAS techniques were chosen to metal analysis. Pollution indices $\left(E F, I_{\text {geo }}\right.$ and $\mathrm{PI}_{\mathrm{N}}$ ) and a comparison with sediment quality guidelines (UET, ERL, ERM, TEL and PEL of NOAA) were conducted in order to evaluate the potential metal impacts over the area. Principal Component Analysis (PCA) and Pearson correlation results showed the importance of organic matter content and the fine-grained fraction of sediments on the control of the bioavailable metals distribution. The Paraguaçu estuary already has anthropogenic enrichment relative to the background level, especially for Mn, whose values exceeded almost 30 times the background at one site $\left(\mathrm{Mn}: 1197.30 \mathrm{mg} \mathrm{kg} \mathrm{g}^{-1}\right.$ ). However, metal levels are still below the reference values with the exception of $\mathrm{Hg}$ at one site (Hg: $0.25 \mathrm{mg} \mathrm{kg}^{-1}$, exceeded TEL and ERL).
\end{abstract}

(c) 2015 Elsevier Ltd. All rights reserved.

\section{Introduction}

Metals are natural components of ecosystems and their optimal concentration in the organisms is a sine qua non characteristic for healthy biotic activities (Gao et al., 2014). However, when found in high concentrations in the sediment or water, those elements might become a threat to the aquatic ecosystem due to its inherent ecotoxicity features, persistence and tendency to biomagnificate. Therefore, the high concentrations of such elements in the sediment or water may lead to human intoxication through food web (Zahra et al., 2014; Jin et al., 2015; Wang et al., 2015).

Ecotoxicological studies which connect ecology and toxicology aim to understand and predict effects of chemicals (metals, PAHs, PCBs, etc.) on natural communities under realistic exposure conditions (Chapman, 2002). Their methods have been applied with more importance to estimate the quality of water, sediments, soils, and the atmosphere (Reis et al., 2013; Jiang et al., 2014; Camargo et al., 2015). Camargo et al. (2015) asserts that sediments are an

\footnotetext{
* Corresponding author at: Núcleo de Estudos Ambientais, Instituto de Geociências, Universidade Federal da Bahia (UFBA), Campus de Ondina, 40170-290 Salvador, BA, Brazil.

E-mail address: icarotam@gmail.com (Í.T.A. Moreira).
}

important indicator of the health of aquatic ecosystems because they naturally work as a metal reservoir, due to the capacity of holding more than $90 \%$ of metals in the aquatic environment (Zahra et al., 2014). Thus, sediments are a potential secondary source of metals which might be released back into water columns along with changed environmental conditions (Wang et al., 2015).

One method largely used to estimate the degree of metal contamination of a specific area and the potential risks linked to the increase in metal concentrations is to study the bioavailability of the metals in the sedimentation area (Peña-Icart et al., 2014). Metals are considered bioavailable whenever they are dissolved in the water column or interstitial water, incorporated to sediments through weak chemical bonds (i.e. the potentially labile parcel), or in metal complexes, created by a colloidal material such as dissolved organic matter, hydroxyl, carbonates, and sulfites (Bayen, 2012). The bioavailability and ecotoxicity of metals in sediment depend on the interactions between many variables such as $\mathrm{pH}$, salinity, redox potential, mineral and organic content and resident biota (Souza et al., 2015).

In order to differentiate the influence caused by natural or anthropogenic sources of metals, simple and integrate indices such as enrichment factor (EF), index of geoaccumulation $\left(I_{\text {geo }}\right)$ and Nemerow synthetic pollution index $\left(\mathrm{PI}_{N}\right)$ are widely applied in 
environmental studies (Wei et al., 2011; Armid et al., 2014; Brady et al., 2014; Chakraborty et al., 2014; de Paula Filho et al., 2015; Hamdoun et al., 2015). Moreover, it is equally important to evaluate the biological adverse risks. Hence, comparisons with sediment quality guidelines (SQGs) are usually done (Bastami et al., 2015; Merhaby et al., 2015; Wang et al., 2015).

The Todos os Santos Bay, (BTS, acronym in Portuguese for Baía de Todos os Santos), is a region surrounded by several small towns and cities with industrial activity, such as Industrial Centre of Aratu (CIA), Landulpho Alves refinery (RLAM), and Paraguaçu shipyard. The activities performed by those industrial centers may potentially degrade the local environment and the surrounding estuaries (Hatje et al., 2009). Paraguaçu's estuary is located westward from BTS and it is largely influenced by the tide currents inside the bay due to the water stream regularization done by the Paraguaçu's Dam (Pedra do Cavalo Dam), built $40 \mathrm{~km}$ away from the mouth of the river (Mestrinho, 1998; CRA, 2004). Then, it is clear that the impacts on the Todos os Santos Bay tend to occur more intensively around the described region. It is important to highlight that the construction of a new shipyard on the Paraguaçu's estuary will increase the traffic and furthermore the risk of contamination by metals and oil spills (Moreira et al., 2013).

Along the estuarine area of Paraguaçu River, there is a large and healthy mangrove field which tends to be attached to a high fishery production. Rima (2009) states that such activity is the main support for several towns in the area. Those resources are classically one of the first to be reached by metal contamination and can therefore expose the population of those towns or any other consumer to risks. For this reason, it is necessary to point out that ecological studies are paramount to help managing the local environment. Having said that, the present study aims to: (1) study the relationship between bioavailable metals concentrations, geochemical data (organic matter, nitrogen and phosphorus) and sediment grain size; (2) quantify the extent of metal pollution using enrichment factor (EF), geoaccumulation index $\left(I_{\text {geo }}\right)$ and Nemerow synthetic pollution index $\left(\mathrm{PI}_{\mathrm{N}}\right)$; (3) assess ecological risk of sediments using Upper Effects Threshold (UET) for freshwater sediments, Effects Range-Low/Effects Range-Median (ERL/ERM) for marine sediments and Threshold Effect Level/Probable Effect Level (TEL/PEL) for both sediment type.

\section{Materials and methods}

\subsection{Study area}

The Paraguaçu River is the longest river entirely located in the state of Bahia and the main tributary of the Todos os Santos Bay. This system is very important for the local communities, because it provides the main source of food resources and income (i.e. consumption and commercialization of fish and shellfish) to these populations (Barros et al., 2008). The Paraguaçu River is originated by a natural spring in the Sincorá Mountains, around the Chapada Diamantina region. Throughout its path, it incorporates many tributaries along its $540 \mathrm{~km}$ of length. With a drainage area of $55,317 \mathrm{~km}^{2}$, the river encompasses 84 small towns including about $10 \%$ of the state total area. Its area has a precipitation ranging from $1200 \mathrm{~mm}$ to $1600 \mathrm{~mm}$ and an average monthly temperature of $24{ }^{\circ} \mathrm{C}$ with the smallest annual temperature range of $5{ }^{\circ} \mathrm{C}$ due to the proximity to the ocean. The period between November and March has the highest mean monthly temperatures while the months of July and August have the lowest ones. Several anthropogenic activities potentially influence the system environmental quality, including solid wastes, agriculture, animal husbandry, domestic effluents and industrial and mining activities (Mestrinho, 1998).

\subsection{Sediment sampling and pretreatment}

The sediment gathering process happened on the 18th of July of 2013 , during the rainy season on the estuary. Before the gathering survey, satellite images and maps were analyzed to previously choose the sampling sites cities (Fig. 1). The sites were far enough to minimize spatial autocorrelation effects and to maximize differences in metal contamination between the sampling sites (Couillard et al., 2008). Two sites were chosen on Salinas da Margarida's beach. One of them, P 06, is facing the Todos os Santos Bay, in order to get more influence of the bay water. The geographic coordinates of each gathering point were georeferenced on the SIRGAS 2000 datum, using a Global Position System (GPS) of the model Garmin Etrex Vista H. A composite sampling process was performed, thus creating triplicates for each sampling spot. A total of 18 surface sediments were taken from the sampling points on the top $10 \mathrm{~cm}$ of depth using stainless steel sampler and homogenized inside a glass container. All the containers used for the sampling were previously cleaned, decontaminated, and therefore labelled. The samples that would be used to analyze arsenic, metals, organic matter $(\mathrm{OM})$, total nitrogen (TN), available phosphorous $\left(P_{\text {ava }}\right)$ and total phosphorus (TP) concentrations were kept in glass containers, and the samples for analysis of grain size were kept inside plastic bags. The samples were immediately transported to the laboratory and then stored in a freezer $\left(-20^{\circ} \mathrm{C}\right)$. The frozen sediment was initially dried in a lyophilizer, Liotop L018 model, and then disaggregated and sieved in $0.5 \mathrm{~mm}$ and $2.0 \mathrm{~mm}$ sieves. The sediments smaller than $0.5 \mathrm{~mm}$ were used to obtain the concentration of As, metals, TN, OM, $P_{\text {ava }}$ and TP. The sediments smaller than $2 \mathrm{~mm}$ were used for the grain size analysis.

\subsection{Determination of metals}

For the measurement of partial metal concentrations, acid digestion was performed in each sediment sample using USEPA method 3051A. $1.0 \mathrm{~g}$ of sediment was digested in $10 \mathrm{ml}$ of ultrapure $\mathrm{HNO}_{3}$ (Merck - Darmstadt, Germany) and $10 \mathrm{ml}$ of ultrapure $\mathrm{H}_{2} \mathrm{O}$ (Milli-Q system) using microwave oven (Provecto DGT 100 model), filtered, and diluted. Partial metal concentration of $\mathrm{Al}, \mathrm{Ba}$, $\mathrm{Ca}, \mathrm{Pb}, \mathrm{Co}, \mathrm{Cu}, \mathrm{Cr}, \mathrm{Fe}, \mathrm{Mg}, \mathrm{Mn}, \mathrm{Mo}, \mathrm{Ni}, \mathrm{K}, \mathrm{V}, \mathrm{Zn}$ and metalloid As concentration were determined using Inductively Coupled Plasma Optical Emission Spectrometry (ICP-OES - Agilent Technologies 700 series model). The concentration of the metal $\mathrm{Hg}$ was the only one obtained through the Cold Vapor Atomic Absorption Spectrometry (CV-AAS - Varian SpectrAA 220 SF model). The partial metal concentrations were expressed in $\mathrm{mg} \mathrm{kg}^{-1}$ of dry sediments. The same analysis done in the samples was used for the analytical blanks. All plastic, quartz and glassware used in analysis were soaked in $\mathrm{HNO}_{3}$ (10\%) (Merck) for at least $24 \mathrm{~h}$ and rinsed repeatedly with ultra-pure water. The Quality Assurance/Quality Control $(\mathrm{QA} / \mathrm{QC})$ procedures involved the use of standard reagents and the analysis of the Certified Reference Material STSD-4 (estuarine sediment). The results of the analysis of some metals using this certified reference sediment are presented in Table 1, together with the quantification limits (QL) for each element.

\subsection{Measurement of other sediment parameters}

OM concentration was determined by EMBRAPA method (EMBRAPA, 2009), which is based on exothermic reactions and oxidation of organic matter by $\mathrm{K}_{2} \mathrm{Cr}_{2} \mathrm{O}_{7}$ (Sigma - St. Louis, MO, USA) and concentrated $\mathrm{H}_{2} \mathrm{SO}_{4}$ (J.T. Baker - Deventer, Holland). Sediment textural classification, i.e. the proportion of sand, silt and clay (\%), was determined using a LASER particle size analyzer (Cilas 1064 model) with a measuring range of 4-500 $\mu \mathrm{m}$, according the method described by Folk and Ward (1957). Textural 


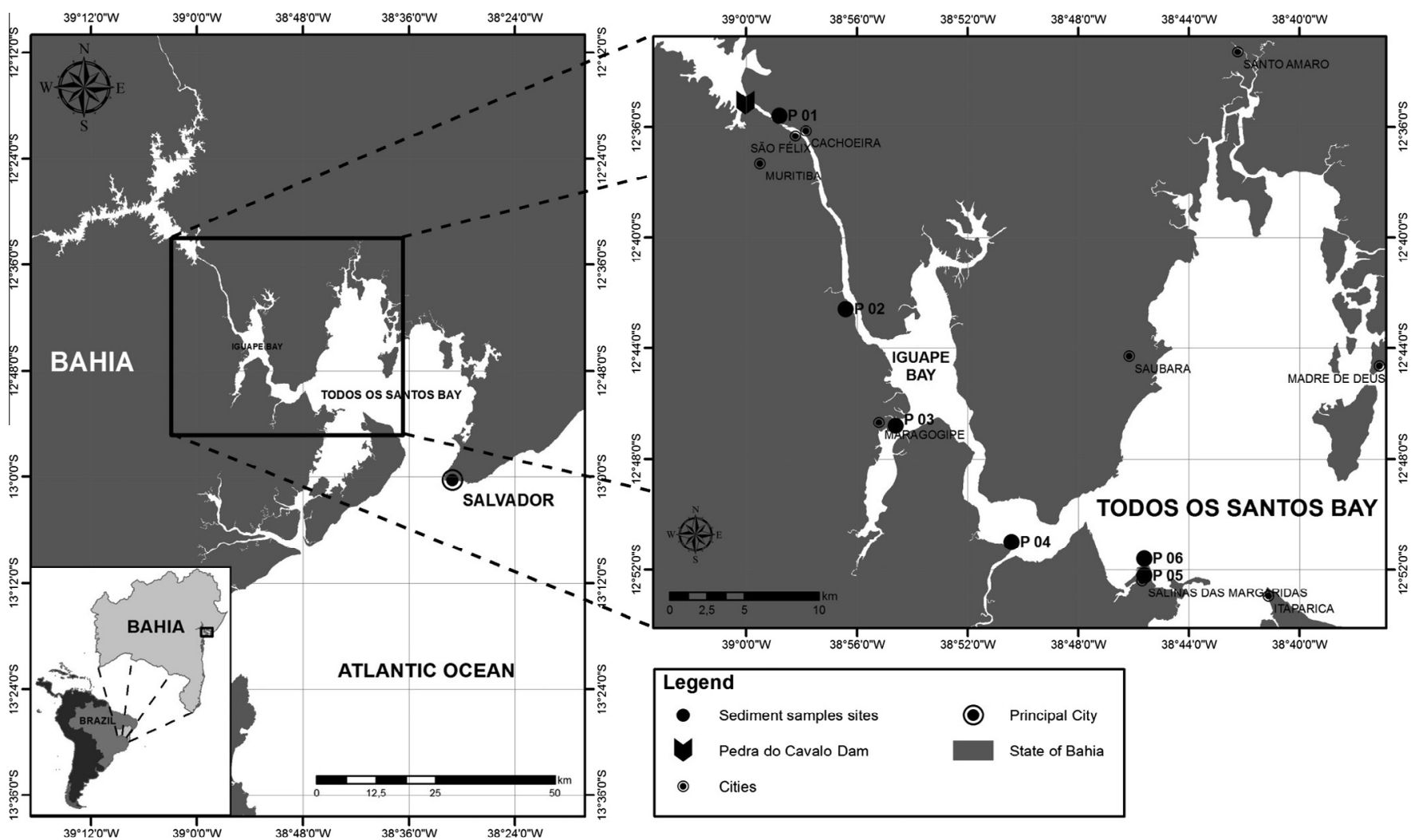

Fig. 1. Map of the Paraguaçu River estuary and distribution of sampling sites.

Table 1

Results of the accuracy and precision test of the metal analyses in the certified reference sediments.

\begin{tabular}{|c|c|c|c|c|c|}
\hline Element & Certified reference & Quantification limits $\left(\mathrm{mg} \mathrm{kg}^{-1}\right)$ & Certified concentration $\left(\mathrm{mg} \mathrm{kg}^{-1}\right)$ & Observed concentration $\left(\mathrm{mg} \mathrm{kg}^{-1}\right)$ & Percent recovery $(\%)$ \\
\hline $\mathrm{Pb}$ & STSD-4 & 1.76 & 13 & $16.0 \pm 1.0$ & 1.23 \\
\hline $\mathrm{Cu}$ & STSD-4 & 0.75 & 66 & $68.0 \pm 2.8$ & 1.03 \\
\hline $\mathrm{Ni}$ & STSD-4 & 2.46 & 23 & $26.0 \pm 0.8$ & 1.13 \\
\hline V & STSD-4 & 1.22 & 51 & $56.4 \pm 1.0$ & 1.11 \\
\hline Element & Certified reference & Quantification limits $\left(\mathrm{mg} \mathrm{kg}^{-1}\right)$ & Certified concentration (\%) & Observed concentration (\%) & Percent recovery (\%) \\
\hline $\mathrm{Fe}$ & STSD-4 & 1.33 & 2.6 & $2.8 \pm 0.9$ & 1.08 \\
\hline
\end{tabular}

classification was based on the relative percentage of the different size fractions (clay $(\mathrm{CL})<4 \mu \mathrm{m} ; 4-63 \mu \mathrm{m}$ silt $(\mathrm{ST}) ; 63-130$ very fine sand (VFS); 130-250 $\mu \mathrm{m}$ fine sand (FS); 250-500 $\mu \mathrm{m}$ medium sand (MS); coarse sand (CS) $>500 \mu \mathrm{m}$ ). The total nitrogen concentration on the sediment was determined by the Kjeldahl method (EMBRAPA, 2009) which has two steps: (1) organic nitrogen transformation in ammonium $\left(\mathrm{NH}_{4}^{+}\right)$and (2) determination of $\mathrm{NH}_{4}^{+}$ digested on step 1 by distillation with $\mathrm{NaOH} 15 \%$ (F. Maia - São Paulo, Brazil). The method described by Aspila et al. (1976) was carried out in order to obtain the available phosphorus concentration. An estimate of total phosphorus was made with partial acid digestion, as for metal determination, as done by Taylor and Boult (2007) and Hoff et al. (2014). To assure the proceedings reliability, all the analyses were done with analytical blanks.

\subsection{Quantification of sediment pollution}

\subsubsection{Enrichment factor (EF)}

The enrichment factor is an index used to differentiate the natural metal sources from the anthropogenic ones. It is also used as a tool to reduce the interference of the grain size and mineral composition of the sediments on metal variability (Abrahim and
Parker, 2008; Qingjie et al., 2008). Normalized EF of metals in Paraguaçu sediments of each site was calculated using Eq. (1). Aluminum ( $\mathrm{Al}$ ) was used as a reference element to calculate anthropogenic metal enrichments as described by CRA (2004) and Brady et al. (2015). Concentration of metals reported by CRA (2004), Otero et al. (2008) and EIA (2009) was used as background values for the metals and metalloid As. EF values are then categorized in six major groups, presented on Table 2.

$\mathrm{EF}=\frac{\left(C_{\mathrm{x}} / C_{\mathrm{EN}}\right)_{\text {sample }}}{\left(C_{\mathrm{x}} / C_{\mathrm{EN}}\right)_{\text {background }}}$

$C_{\mathrm{x}}$ is the concentration of the analyzed metal and $C_{\mathrm{EN}}$ is the concentration of the normalizing element.

\subsubsection{Geoaccumulation index $\left(I_{\text {geo }}\right)$}

The geoaccumulation index is obtained through the Eq. (2), created by Müller (1979), to estimate the enrichment of the metals within a sample using the background level of the metallic component itself. This index is being widely used in trace metal studies on sediments and soils (Wei et al., 2011; Armid et al., 2014; Chakraborty et al., 2014). $I_{\text {geo }}$ classes to interpret the results are shown on Table 2. 
Table 2

Enrichment factor $(\mathrm{EF})$, geoaccumulation index $\left(I_{\text {geo }}\right)$ and Nemerow synthetic pollution index $\left(\mathrm{PI}_{\mathrm{N}}\right)$ sediment qualifications.

\begin{tabular}{|c|c|c|c|c|c|}
\hline Classes EF & Sediment quality & $I_{\text {geo }}$ & Sediment quality & Classes $\mathrm{PI}_{\mathrm{N}}$ & Sediment quality \\
\hline $\mathrm{EF}<1$ & No enrichment & $I_{\text {geo }} \leqslant 0$ & Unpolluted & $\mathrm{PI}_{\mathrm{N}}<2$ & Unpolluted \\
\hline $1 \leqslant \mathrm{EF}<3$ & Minor enrichment & $0<I_{\text {geo }} \leqslant 1$ & Unpolluted to moderately polluted & $2 \leqslant \mathrm{PI}_{\mathrm{N}}<4$ & Low polluted \\
\hline $3 \leqslant \mathrm{EF}<5$ & Moderate enrichment & $1<I_{\text {geo }} \leqslant 2$ & Moderately polluted & $4 \leqslant \mathrm{PI}_{\mathrm{N}}<16$ & Moderately polluted \\
\hline $5 \leqslant \mathrm{EF}<10$ & Moderately severe enrichment & $2<I_{\text {geo }} \leqslant 3$ & Moderately to highly polluted & $16 \leqslant \mathrm{PI}_{\mathrm{N}}<32$ & Strongly polluted \\
\hline $10 \leqslant \mathrm{EF}<25$ & Severe enrichment & $3<I_{\text {geo }} \leqslant 4$ & Highly polluted & $\mathrm{PI}_{\mathrm{N}}>32$ & Extremely polluted \\
\hline $25 \leqslant \mathrm{EF}<50$ & Extremely severe enrichment & $\begin{array}{l}4<I_{\text {geo }} \leqslant 5 \\
I_{\text {geo }}>5\end{array}$ & $\begin{array}{l}\text { Highly to very highly polluted } \\
\text { Very highly polluted }\end{array}$ & & \\
\hline
\end{tabular}

$I_{\text {geo }}=\log _{2}\left(\frac{C_{\mathrm{x}_{\text {sample }}}}{1.5 \times C_{\mathrm{x}_{\text {background }}}}\right)$

$C_{\mathrm{x}}$ is the concentration of the metal being analyzed.

The factor 1.5 is used to minimize the effect of possible variations on the background values associated to the lithological variations in the sediment.

\subsubsection{Nemerow synthetic pollution index $\left(P I_{N}\right)$}

The Nemerow synthetic pollution is an integrated index used to estimate the enrichment for several contaminants, i.e. the total contamination of a specific area, using a single index. In the present study, the single index chosen was the contamination factor calculated by Hakanson (1980) according to the following equation:

$C_{\mathrm{f}}=\frac{M_{\mathrm{x}_{\text {sample }}}}{M_{\mathrm{x}_{\text {background }}}}$

$M_{\mathrm{x}_{\text {sample }}}$ and $M_{\mathrm{x}_{\text {background }}}$ refer to the concentration of a pollutant in the samples and the background respectively.

The $\mathrm{PI}_{\mathrm{N}}$ is largely used in trace metal studies (Cheng et al., 2007; Zhao and Li, 2013; Brady et al., 2014). It is obtained by the Eq. (3) which classifies the data in five groups described by Qingjie et al. (2008) and presented on Table 2.

$\mathrm{PI}_{\mathrm{N}}=\sqrt{\frac{\left(C_{\mathrm{f}_{\mathrm{av}}}\right)^{2}+\left(C_{\mathrm{f}_{\max }}\right)^{2}}{2}}$

$C_{\mathrm{f}_{\mathrm{av}}}$ and $C_{\mathrm{f}_{\max }}$ is respectively the average and maximum value of the contamination factor of all metals in a sample.

\subsection{Statistical analysis}

A Kolmogorov-Smirnov test was carried out to check if variables were normally distributed. The matrix of Pearson Correlation values was used to obtain the degree of association between the variables and to evaluate the effect of the organic matter parameters, size grain, nitrogen, and phosphorous on the metal enrichment. These statistical analyses were performed on statistical software $\mathrm{R}$ in version 3.2.0 from the R-project for Statistical Computing. Principal Component Analysis (PCA) was performed to better quantify the relationship among the variables on this study and to identify the group of geochemically similar samples. This one was performed on Statistica Software for Windows, version 7.0 from Statsoft Inc.

\section{Results and discussion}

\subsection{Sediment characteristics}

The parameters values of the nutrients (organic matter, nitrogen, and phosphorus) and for the grain size are shown in Fig. 2. The sediment of the Paraguaçu estuary seems to have a higher fraction of sand size of grain. The stations P 03, P 04, P 05, P 06 on the margins of the river had a higher fraction of sand as described by Lessa and Dias (2009). Also, the sand faces found in these sampling points are evidence of local high hydrodynamic which interferes on the deposition of fine particles. Previous studies demonstrated that fine-grained sediments facilitate the accumulation of heavier metal and organic matter contents (Bayen, 2012; Yu et al., 2012; Zahra et al., 2014). The concentration of OM on the sediments, obtained through the conversion factor of Van Bemmelem (Garcia et al., 2014), which uses the values of total organic carbon (TOC), ranged from $0.38 \%$ to $3.00 \%$. Those values are considered low for environments like mangroves which are classically enriched in $\mathrm{OM}$ concentrations and therefore can be associated with the high hydrodynamic potential of the region. Besides, the existence of Pedra do Cavalo Dam tends to reduce the nutrients in the discharged water to the estuary. Due to the sedimentation of bloomed phytoplankton in the water column, dams trap nutrients on the reservoirs bottom (Yamamoto, 2003). P 05 was the point with the highest $\mathrm{OM}$ values and this sampling site is located next to a wharf and to a sewage on Salinas da Margarida's beach which are possible sources of OM contamination. P 04 had the smaller values of OM and the highest grain sizes seem to induce the smaller concentration of it. Overall, the percentage of total nitrogen (TN) in the sampling sites was low, ranging from less than the quantification limit to $0.22 \%$. For Kjeldahl method described by EMBRAPA (2009), the QL is 0.08\%. The nitrogen on the environment depends mainly on the decomposition process of the OM (Serna et al., 2014). The biggest TN value was found on P 05, implying a stronger degradation process of $\mathrm{OM}$ on this sampling site. The levels of total $\mathrm{P}$ had values ranging between 58.32, at P 04, and $381.39 \mathrm{mg} \mathrm{kg}^{-1}$, at $\mathrm{P} 01$. $P_{\text {ava }}$ ranged between 40.93 and $230.56 \mathrm{mg} \mathrm{kg}^{-1}$ and was between $48.3 \%$ and $96.6 \%$ of the total $P$. Those values for $P$ match previous studies in the area (EIA, 2009) which indicate that the estuary of Paraguaçu tends to be oligotrophic.

\subsection{Metal concentrations in sediments and comparison with sediment quality guidelines (SQGS)}

The Tables 3 and 4 present the concentrations in $\mathrm{mg} \mathrm{kg}^{-1}$ of the metals and arsenic in the available fraction for the six studied points on the Paraguaçu estuary as well as background values for the study area. The values were compared with quality levels described by the National Oceanic and Atmospheric and Administration (NOAA): Upper Effects Threshold (UET), Effects Range-Low (ERL), Effects Range-Median (ERM), Threshold effect level (TEL) and Probable effect level (PEL). The UET was derived by NOAA as the lowest AET. ${ }^{1}$ ERL and ERM represent respectively the tenth and fiftieth percentile values in the aquatic toxicity dataset, (Lin et al., 2013). TEL represents the concentration threshold below which there are small or no toxic risks to the organisms. The PEL is the minimum value in which several effects start to occur. The site P 01 has no salinity value, and thus its values were the only

\footnotetext{
${ }^{1}$ AET is equivalent to the concentration observed in the highest non-toxic sample.
} 

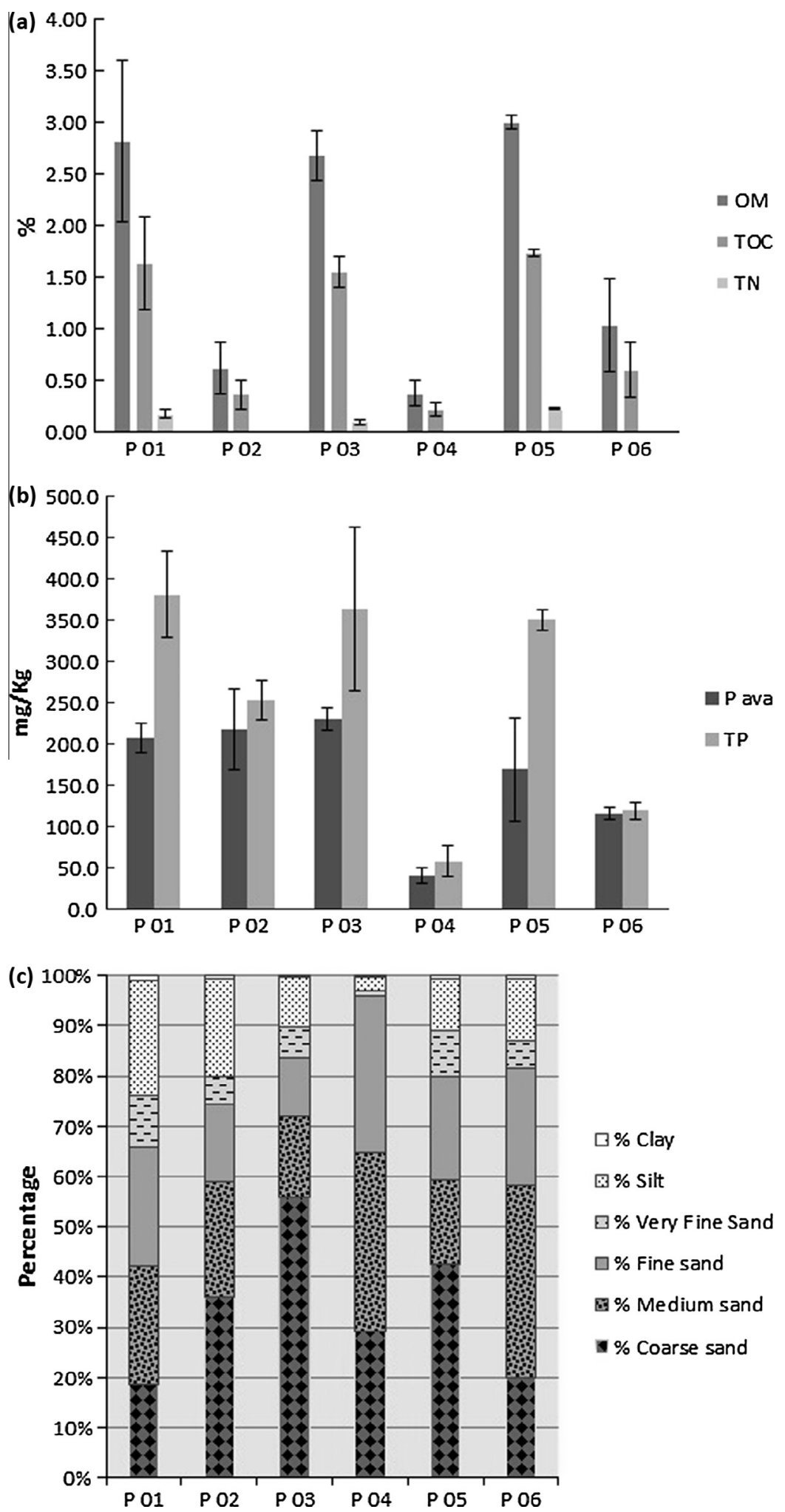

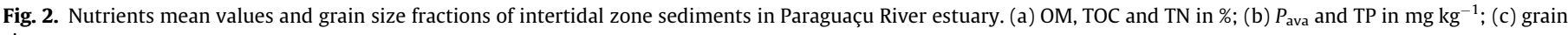
size.

ones compared to the UET, TEL and PEL levels for freshwater sediments.

Between the studied elements, the arsenic and molybdenum were the only ones with values under the QL in all samples. The metals $\mathrm{Al}, \mathrm{Fe}, \mathrm{Mg}, \mathrm{K}$ and $\mathrm{Zn}$ had a higher average concentration on P 05 and lower on P 04. These metals concentrations were ranging over following intervals: $\mathrm{Al}$ : $686.68-8935.02 \mathrm{mg} \mathrm{kg}^{-1}$; $\mathrm{Fe}$ : 1781.43-12184.67 $\mathrm{mg} \mathrm{kg}^{-1}$; $\mathrm{Mg}$ : 441.95-3040.30 $\mathrm{mg} \mathrm{kg}^{-1}$; $\mathrm{K}$ : 268.10-3293.24 $\mathrm{mg} \mathrm{kg}^{-1}$; Zn: $11.81-40.10 \mathrm{mg} \mathrm{kg}^{-1}$. Pb, Co, Cu, $\mathrm{Cr}, \mathrm{Hg}$ and $\mathrm{Ni}$ had their concentration values lower than $\mathrm{QL}$ in at 
Table 3

Metal and As concentrations (average \pm standard deviation) in $\mathrm{mg} \mathrm{kg}^{-1}$ in sediments of the site P 01 .

\begin{tabular}{llllll}
\hline Metals & P 01 & BG & TEL $^{\mathrm{a}}$ & $\mathrm{PEL}^{\mathrm{a}}$ & UET $^{\mathrm{a}}$ \\
\hline $\mathrm{Al}$ & $5005.21 \pm 542.89$ & $558.63^{\mathrm{b}}$ & - & - & - \\
$\mathrm{As}$ & $<\mathrm{QL}$ & $0.05^{\mathrm{d}}$ & 5.90 & 17.00 & 17.00 \\
$\mathrm{Ba}$ & $93.58 \pm 18.44$ & $17.4^{\mathrm{c}}$ & - & - & - \\
$\mathrm{Ca}$ & $1719.51 \pm 323.42$ & $448.56^{\mathrm{b}}$ & - & - & - \\
$\mathrm{Pb}$ & $<\mathrm{QL}$ & $10.21^{\mathrm{e}}$ & 35.00 & 91.30 & 127.00 \\
$\mathrm{Co}$ & $3.09 \pm 0.82$ & $2.20^{\mathrm{e}}$ & - & - & - \\
$\mathrm{Cu}$ & $7.75 \pm 1.43$ & $5.04^{\mathrm{e}}$ & 35.70 & 197.00 & 86.00 \\
$\mathrm{Cr}$ & $25.40 \pm 3.40$ & $6.07^{\mathrm{e}}$ & 37.30 & 90.00 & 95.00 \\
$\mathrm{Fe}$ & $7561.09 \pm 830.37$ & $8885.00^{\mathrm{e}}$ & - & - & 40.000 \\
$\mathrm{Mg}$ & $872.31 \pm 89.96$ & $378.44^{\mathrm{b}}$ & - & - & - \\
$\mathrm{Mn}$ & $388.51 \pm 118.76$ & $41.00^{\mathrm{e}}$ & - & - & 1100.00 \\
$\mathrm{Hg}$ & $0.02 \pm 0.00$ & $0.03^{\mathrm{d}}$ & 0.174 & 0.486 & 0.56 \\
$\mathrm{Mo}$ & $<\mathrm{QL}$ & - & - & - & - \\
$\mathrm{Ni}$ & $5.09 \pm 0.65$ & $1.95^{\mathrm{e}}$ & 18.00 & 36.00 & 43.00 \\
$\mathrm{~K}$ & $299.64 \pm 32.66$ & $216.40^{\mathrm{b}}$ & - & - & - \\
$\mathrm{V}$ & $15.42 \pm 2.06$ & $18.60^{\mathrm{c}}$ & - & - & - \\
$\mathrm{Zn}$ & $23.23 \pm 3.59$ & $2.76^{\mathrm{e}}$ & 123.00 & 315.00 & 520.00 \\
\hline
\end{tabular}

$\mathrm{BG}=$ Background

a SQGs for freshwater sediments; values in $\mathrm{mg} \mathrm{kg}^{-1}$.

b This study.

c CRA (2004).

d EIA (2009).

e Otero et al. (2008).

least one sampling spot. $\mathrm{Pb}, \mathrm{Cu}$ and $\mathrm{Ni}$ had their highest concentration value on P 05, respectively 4.56, 7.96 and $8.02 \mathrm{mg} \mathrm{kg}^{-1}$, while cobalt and chromium had their higher average value on P 01, 3.09 and $25.40 \mathrm{mg} \mathrm{kg}^{-1}$, respectively. The higher average value of $\mathrm{Hg}$ happened on P $06\left(0.25 \mathrm{mg} \mathrm{kg}^{-1}\right)$. This metal had concentration values higher than the background values on P 02, P 05, P 06, and only on P 06 had higher values than TEL and ERL. Previous studies also suggest a presence of $\mathrm{Hg}$ contamination on Todos os Santos Bay (Marins et al., 2004; EIA, 2009). The average concentration of Ba in this study ranged from $11.77 \mathrm{mg} \mathrm{kg}^{-1}$ on P 03 until $93.58 \mathrm{mg} \mathrm{kg}^{-1}$ on $\mathrm{P}$ 01. Ca concentration values ranged from $552.49 \mathrm{mg} \mathrm{kg}^{-1}$ on P 04 and $2111.39 \mathrm{mg} \mathrm{kg}^{-1}$ on P 06 where there is an extensive area with intensive shellfish gathering activity. The degradation of shells may explain the high levels of Ca at this site. Vanadium values ranged from 2.13 to $15.42 \mathrm{mg} \mathrm{kg}^{-1}$, and had higher average concentration on P 01 and lower on P 04 . The mean concentration of $\mathrm{Mn}$ ranged from $21.03 \mathrm{mg} \mathrm{kg}^{-1}$ on $\mathrm{P} 06$ to $1197.30 \mathrm{mg} \mathrm{kg}^{-1}$ on P 04 in which the values of Mn reached 30 times higher than the natural values. This sampling site is located in a region with high anthropic action next to the Paraguaçu shipyard which shows a possible contamination source by the shipyard wastewater (Walker et al., 2005).

Although, the metals in the study had values smaller than the reference values established by NOAA, except $\mathrm{Hg}$, that had concentration higher than TEL and ERL on P 06, the majority of the metals presented high values relatively to the background level of the region. P 04 had the smallest concentrations for the great majority of the metals, except Mn. This sampling spot had higher sandy texture which can be associated to the low concentrations of metals, after all low concentrations of metals are generally associated to finer sediment parcels. P 05 had the higher concentration values for the majority of the metals. As it has been said before, this point is located on Salinas da Margarida's beach, close to a wharf and the sewage disposal of the urban center. High metal concentrations were related, in previous environmental studies, with domestic effluents (Al-Ghais, 2013; Naser, 2013; Velusamy et al., 2014) and oil residue from boats (Moldanová et al., 2009).

\subsection{Evaluation of sediment pollution}

\subsubsection{Enrichment factor (EF)}

The Enrichment Factors were calculated for $\mathrm{Ba}, \mathrm{Pb}, \mathrm{Co}, \mathrm{Cu}, \mathrm{Cr}, \mathrm{Fe}$, $\mathrm{Mn}, \mathrm{Hg}, \mathrm{Ni}, \mathrm{V}$ and $\mathrm{Zn}$ (Table 5). They show that overall, there is no anthropogenic enrichment $(\mathrm{EF}<1)$ for the metals $\mathrm{Pb}, \mathrm{Co}, \mathrm{Cu}, \mathrm{Cr}, \mathrm{Fe}$, $\mathrm{Ni}$ and V. P 01 values had minor enrichment for Mn (EF 1.06). P 02 had minor enrichment for Zn (EF 1.14). P 03 and P 05 did not have any enrichment. P 06 had a minor enrichment for $\mathrm{Hg}$ (EF 1.65) and Zn (1.79). P 04 had major anthropic enrichment for some metals. As seen on 3.2, this sampling site is located next to Paraguaçu Shipyard, in a place that constantly receives shipyard wastewater. This explains the moderate enrichment on Ba (EF 3.21) and $\mathrm{Zn}(\mathrm{EF}$ 3.48) and the severe enrichment of Mn (EF 23.76) (Walker et al., 2005). It is well known that Mn is the eleventh most abundant element in earth crust (Duman et al., 2007) and therefore its accumulation and enrichment are influenced by both natural processes

Table 4

Metal and As concentrations (average \pm standard deviation) in $\mathrm{mg} \mathrm{kg}^{-1}$ in sediments of the sites P 02-P 06. Values over SQGs are marked in bold.

\begin{tabular}{|c|c|c|c|c|c|c|c|c|c|c|}
\hline Metals & Р 02 & Р 03 & Р 04 & P 05 & Р 06 & BG & $\mathrm{TEL}^{\mathrm{a}}$ & $\mathrm{ERL}^{\mathrm{a}}$ & $\mathrm{PEL}^{\mathrm{a}}$ & $\mathrm{ERM}^{\mathrm{a}}$ \\
\hline $\mathrm{Al}$ & $2565.54 \pm 204.67$ & $4012.38 \pm 405.41$ & $686.68 \pm 138.94$ & $8935.02 \pm 378.57$ & $3346.50 \pm 311.11$ & $558.63^{b}$ & - & - & - & - \\
\hline As & $<Q L$ & $<Q L$ & $<Q L$ & $<Q L$ & $<Q L$ & $0.05^{\mathrm{d}}$ & 7.24 & 8.20 & 41.60 & 70.00 \\
\hline Ва & $19.79 \pm 5.84$ & $11.77 \pm 1.97$ & $68.76 \pm 7.47$ & $19.08 \pm 0.54$ & $42.83 \pm 5.53$ & $17.40^{c}$ & 130.1 & - & - & - \\
\hline $\mathrm{Ca}$ & $1415.02 \pm 102.84$ & $1854.21 \pm 325.39$ & $552.49 \pm 99.99$ & $2019.06 \pm 107.00$ & $2111.39 \pm 90.23$ & $448.56^{\mathrm{b}}$ & - & - & - & - \\
\hline $\mathrm{Pb}$ & $<Q L$ & $<Q L$ & $<\mathrm{QL}$ & $4.56 \pm 0.71$ & $<Q L$ & $10.21^{\mathrm{e}}$ & 30.24 & 46.70 & 112.00 & 218.00 \\
\hline Co & $<Q L$ & $<Q L$ & $2.15 \pm 0.80$ & $1.06 \pm 0.21$ & $<\mathrm{QL}$ & $2.20^{\mathrm{e}}$ & - & - & - & - \\
\hline $\mathrm{Cu}$ & $<\mathrm{QL}$ & $2.60 \pm 0.67$ & $1.25 \pm 1.87$ & $7.96 \pm 0.35$ & $0.94 \pm 0.86$ & $5.04^{\mathrm{e}}$ & 18.70 & 34.00 & 108.00 & 270.00 \\
\hline $\mathrm{Cr}$ & $5.30 \pm 0.71$ & $7.51 \pm 1.00$ & $<Q L$ & $23.07 \pm 1.16$ & $9.01 \pm 1.05$ & $6.07^{\mathrm{e}}$ & 52.30 & 81.00 & 160.00 & 370.00 \\
\hline $\mathrm{Fe}$ & $3819.66 \pm 267.93$ & $5111.38 \pm 610.88$ & $1781.43 \pm 257.42$ & $12184.67 \pm 520.05$ & $5936.15 \pm 748.74$ & $8885.00^{\mathrm{e}}$ & - & - & - & - \\
\hline $\mathrm{Mg}$ & $1027.37 \pm 74.87$ & $1517.35 \pm 212.39$ & $441.95 \pm 56.06$ & $3040.30 \pm 80.28$ & $1039.69 \pm 108.82$ & $378.44^{\mathrm{b}}$ & - & - & - & - \\
\hline $\mathrm{Mn}$ & $38.78 \pm 4.72$ & $25.52 \pm 3.33$ & $1197.30 \pm 118.42$ & $67.61 \pm 2.62$ & $21.03 \pm 2.74$ & $41.00^{\mathrm{e}}$ & - & - & - & - \\
\hline $\mathrm{Hg}$ & $0.05 \pm 0.00$ & $<Q L$ & $<Q L$ & $0.04 \pm 0.01$ & $0.25 \pm 0.00$ & $0.03^{d}$ & 0.13 & 0.15 & 0.70 & 0.71 \\
\hline Mo & $<Q L$ & $<\mathrm{QL}$ & $<Q \mathrm{QL}$ & $<Q L$ & $<\mathrm{QL}$ & - & - & - & - & - \\
\hline $\mathrm{Ni}$ & $<\mathrm{QL}$ & $<Q L$ & $<\mathrm{QL}$ & $8.02 \pm 0.66$ & $<Q L$ & $1.95^{\mathrm{e}}$ & 15.90 & 20.90 & 42.80 & 51.60 \\
\hline $\mathrm{K}$ & $811.98 \pm 45.65$ & $1286.18 \pm 154.02$ & $268.10 \pm 51.29$ & $3293.24 \pm 133.95$ & $914.66 \pm 136.27$ & $216.40^{\mathrm{b}}$ & - & - & - & - \\
\hline V & $5.94 \pm 0.48$ & $8.23 \pm 1.12$ & $2.13 \pm 0.42$ & $12.26 \pm 0.50$ & $11.25 \pm 1.82$ & $18.60^{c}$ & - & - & - & - \\
\hline $\mathrm{Zn}$ & $14.46 \pm 1.95$ & $19.62 \pm 4.92$ & $11.81 \pm 2.38$ & $40.10 \pm 1.96$ & $29.58 \pm 20.48$ & $2.76^{\mathrm{e}}$ & 124.00 & 150.00 & 271.00 & 410.00 \\
\hline
\end{tabular}

BG = Background.

a SQGs for marine sediments, values in $\mathrm{mg} \mathrm{kg}^{-1}$.

b This study.

c CRA (2004).

d EIA (2009).

e Otero et al. (2008). 
Table 5

Enrichment factors and Nemerow synthetic pollution index for selected elements (by site) in surface sediments of Paraguaçu River estuary.

\begin{tabular}{|c|c|c|c|c|c|c|c|c|c|c|c|c|}
\hline \multirow[t]{2}{*}{ Sites } & \multicolumn{11}{|c|}{ Enrichment factors } & \multirow[t]{2}{*}{$\mathrm{PI}_{\mathrm{N}}$} \\
\hline & $\mathrm{Ba}$ & $\mathrm{Pb}$ & Co & $\mathrm{Cu}$ & $\mathrm{Cr}$ & $\mathrm{Fe}$ & Mn & $\mathrm{Hg}$ & $\mathrm{Ni}$ & V & $\mathrm{Zn}$ & \\
\hline P 01 & 0.60 & * & 0.16 & 0.17 & 0.47 & 0.09 & 1.06 & 0.08 & 0.29 & 0.09 & 0.94 & 7.28 \\
\hline P 02 & 0.25 & * & * & * & 0.19 & 0.09 & 0.21 & 0.44 & * & 0.07 & 1.14 & 3.95 \\
\hline P 03 & 0.09 & * & * & 0.07 & 0.17 & 0.08 & 0.09 & * & * & 0.06 & 0.99 & 5.33 \\
\hline P 04 & 3.21 & * & 0.79 & 0.20 & ${ }^{*}$ & 0.16 & 23.76 & ${ }^{*}$ & * & 0.09 & 3.48 & 20.95 \\
\hline P 05 & 0.07 & 0.03 & 0.03 & 0.10 & 0.24 & 0.09 & 0.10 & 0.11 & 0.26 & 0.04 & 0.91 & 11.65 \\
\hline P 06 & 0.41 & & & 0.03 & 0.25 & 0.11 & 0.09 & 1.65 & & 0.10 & 1.79 & 8.00 \\
\hline
\end{tabular}

Sites of metal concentration < QL (quantification limit).

and anthropogenic activities. However, such a high EF value on $\mathrm{P}$ 04 shows clearly the anthropic contribution for this metal on this site. Hatje et al. (2009) found similar values for $\mathrm{Cu}, \mathrm{Pb}, \mathrm{Hg}, \mathrm{Cr}, \mathrm{Ni}$ e Zn on the Todos os Santos Bay. Fernández-Cadena et al. (2014) also found similar values on mangroves of the Estero Salado river, for the metals $\mathrm{V}, \mathrm{Cr}$ e $\mathrm{Zn}$, and higher for $\mathrm{Co}, \mathrm{Ni}, \mathrm{Cu}$ e $\mathrm{Pb}$.

\subsubsection{Geoaccumulation index $\left(I_{\text {geo }}\right)$}

The Geoaccumulation Index values, calculated for the selected metals (Table 6), indicate a more enriched environment than that suggested by the values of EF. Only $I_{\text {geo }}$ values of $\mathrm{Pb}, \mathrm{Co}, \mathrm{Cu}, \mathrm{Fe}$, and $\mathrm{V}$ indicated no pollution in sediment samples. $\mathrm{P} 01$ presented the higher amount of metals enriched by anthropic activity: P 01: $\mathrm{Al}\left(I_{\text {geo }} 2.58\right), \mathrm{Ba}\left(I_{\text {geo }} 1.84\right), \mathrm{Cr}\left(I_{\text {geo }} 1.48\right), \mathrm{Mn}\left(I_{\text {geo }} 2.66\right)$ and $\mathrm{Zn}\left(I_{\text {geo }}\right.$ 2.49), followed by P 05: Al ( $\left.I_{\text {geo }} 3.41\right), \mathrm{Cr}$ ( $\left.I_{\text {geo }} 1.34\right), \mathrm{Ni}\left(I_{\text {geo }} 1.45\right)$ and $\mathrm{Zn}\left(I_{\text {geo }} 3.28\right)$. Those two sampling points, even having anthropic contribution for several metals, had pollution levels mainly moderated. Among the metals, $\mathrm{Zn}$ was the only one with enrichment in all sites and high pollution on P 05. It is important to highlight that, the same way as EF, Mn showed the highest accumulation of the study in site P $04\left(I_{\text {geo }} 4.28\right)$ indicated a high to very high pollution. Boaventura (2011) found similar geoaccumulation indices for $\mathrm{Cr}$, Mn, and Fe, lower values for $\mathrm{Zn}$ and higher values for $\mathrm{Cu}$ in mangroves on Madre de Deus Island and Todos os Santos Bay. Wu et al. (2014) also found similar results for $\mathrm{Cr}, \mathrm{Cu}$, $\mathrm{Hg}$, and $\mathrm{Ni}$ and lower values for $\mathrm{Zn}$ in coast of Bohai Bay, Northern China.

The method of $I_{\text {geo }}$ which was originally designed for river sediments (Zhao and Li, 2013) has largely been used to evaluate enrichment of metals in other environments, including mangrove ecosystems (Magesh et al., 2013; Veerasingam et al., 2015). This method differs from other indices of metal enrichment due to the log function presented on $I_{\text {geo }}$ calculation and a background multiplication of 1.5 (Abrahim and Parker, 2008).

\subsubsection{Nemerow synthetic pollution index $\left(P I_{N}\right)$}

This index defers from EF and $I_{\text {geo }}$ because it is not a simple index which means that while the previous ones evaluate the influence of each contaminant separately, the $\mathrm{PI}_{\mathrm{N}}$ it is an integrated index. It takes into account the degree of contribution of all contaminants for the same sampling site (Qingjie et al., 2008). The results of this index are shown in Table 5. The same way as $I_{\text {geo, }}$, this index was more sensitive than $\mathrm{EF}$, and it indicates that Paraguaçu estuary is moderately polluted at sites $\mathrm{P} 01\left(\mathrm{PI}_{\mathrm{N}} 7.28\right)$, $\mathrm{P} 02\left(\mathrm{PI}_{\mathrm{N}}\right.$ 3.95), $\mathrm{P} 03\left(\mathrm{PI}_{\mathrm{N}}\right.$ 5.33), $\mathrm{P} 05\left(\mathrm{PI}_{\mathrm{N}} 11.65\right)$ and $\mathrm{P} 06\left(\mathrm{PI}_{\mathrm{N}}\right.$ 8.00 ). This suggests contamination by one or more elements at most of the sites. $\mathrm{PI}_{\mathrm{N}}$ also shows that the sediment health of the site P 04, near São Roque city, is a concern due to the high enrichment of $\mathrm{Mn}$ in the area. Comparing the results obtained for the Paraguaçu estuary with the one published by Brady et al. (2014) for Deception Bay in Australia, it is noticeable that Paraguaçu's surroundings have higher contamination than Deception Bay.

\subsection{Statistical results}

The correlation coefficient matrix including nutrients (OM, TOC, $\mathrm{TN}, P_{\text {ava }}$ and TP), grain size fractions (MS, FS, VFS, ST and CL) and metals (Al, Ba, Ca, Pb, Co, Cu, Cr, Fe, Mg, Mn, Hg, Ni, K, V and Zn) are shown in Table 7 . This parametric test was carried out after the results of normally distributed data given by KolmogorovSmirnov test. Arsenic and molybdenum were not included as variables on the statistical analysis because they have values $<Q L$ in all samples. Due to the method of determining sediment textural class, the size grain fraction "coarse sand" was also taken out of the statistical analysis. In order to classify the ' $r$ ' values, it was used the class description of Santos (2007). A significant and positive correlation coefficient $(r>0.8)$ suggests a similar geochemical behavior and/or a common source material of the elements.

There was a positive correlation between the three smallest grain size fractions (very fine sand, silt and clay) and both the nutrients variables (TOC, OM, TN, $P_{\text {ava }}$ and TP) and majority of metals. Silt and clay are known to provide large surface areas which adsorb $\mathrm{OM}$ and high cation exchange capacity for contaminants (Bayen, 2012; Song et al., 2014). In this study, the very fine sand was dominant over silt and clay in retaining metals and nutrients. It also had higher positive correlation values with those variables. This helps to explain the low metal concentration on P 04, since it had the lowest percentage of very fine sand (1.07\%). The metals, in its majority, had positive correlation with the nutrients. $\mathrm{Al}, \mathrm{Cu}, \mathrm{Cr}$, Fe and $\mathrm{Ni}$, had the strongest positive correlations, and this is a

Table 6

Geoaccumulation indices for selected elements (by site) in surface sediments of Paraguaçu River estuary.

\begin{tabular}{|c|c|c|c|c|c|c|c|c|c|c|c|c|}
\hline \multirow[t]{2}{*}{ Sites } & \multicolumn{12}{|c|}{ Geoaccumulation indices } \\
\hline & $\mathrm{Al}$ & $\mathrm{Ba}$ & $\mathrm{Pb}$ & Co & $\mathrm{Cu}$ & $\mathrm{Cr}$ & $\mathrm{Fe}$ & Mn & $\mathrm{Hg}$ & $\mathrm{Ni}$ & V & $\mathrm{Zn}$ \\
\hline P 01 & 2.58 & 1.84 & * & -0.09 & 0.04 & 1.48 & -0.82 & 2.66 & -0.99 & 0.80 & -0.86 & 2.49 \\
\hline Р 02 & 1.61 & -0.40 & * & * & * & -0.78 & -1.80 & -0.67 & 0.43 & * & -2.23 & 1.80 \\
\hline Р 03 & 2.26 & -1.15 & * & $*$ & -1.54 & -0.28 & -1.38 & -1.27 & * & * & -1.76 & 2.24 \\
\hline Р 04 & -0.29 & 1.40 & * & -0.62 & -2.60 & $*$ & -2.90 & 4.28 & * & ${ }^{*}$ & -3.71 & 1.51 \\
\hline P 05 & 3.41 & -0.45 & -1.75 & -1.64 & 0.07 & 1.34 & -0.13 & 0.14 & 0.22 & 1.45 & -1.19 & 3.28 \\
\hline P 06 & 2.00 & 0.71 & $*$ & & -3.01 & -0.02 & -1.17 & -1.55 & 2.72 & & -1.31 & 2.84 \\
\hline
\end{tabular}

* Sites of metal concentration < QL (quantification limit). 
Table 7

Pearson's correlation coefficients $(r)$ among nutrients, grain size and metals variables $(n=6)$.

\begin{tabular}{|c|c|c|c|c|c|c|c|c|c|c|c|c|c|c|c|c|c|c|c|c|c|c|c|c|c|}
\hline & $\mathrm{OM}$ & TOC & $\mathrm{TN}$ & $P_{\text {ava }}$ & TP & MS & FS & VFS & ST & CL & $\mathrm{Al}$ & $\mathrm{Ba}$ & $\mathrm{Ca}$ & $\mathrm{Pb}$ & Co & $\mathrm{Cu}$ & $\mathrm{Cr}$ & $\mathrm{Fe}$ & $\mathrm{Mg}$ & $\mathrm{Mn}$ & $\mathrm{Hg}$ & $\mathrm{Ni}$ & $\mathrm{K}$ & $\mathrm{V}$ & $\mathrm{Zn}$ \\
\hline OM & 1.00 & & & & & & & & & & & & & & & & & & & & & & & & \\
\hline TOC & 1.00 & 1.00 & & & & & & & & & & & & & & & & & & & & & & & \\
\hline $\mathrm{TN}$ & 0.93 & 0.93 & 1.00 & & & & & & & & & & & & & & & & & & & & & & \\
\hline$P_{\text {ava }}$ & 0.59 & 0.59 & 0.43 & 1.00 & & & & & & & & & & & & & & & & & & & & & \\
\hline TP & 0.88 & 0.88 & 0.80 & 0.88 & 1.00 & & & & & & & & & & & & & & & & & & & & \\
\hline MS & -0.74 & -0.74 & -0.70 & -0.80 & -0.91 & 1.00 & & & & & & & & & & & & & & & & & & & \\
\hline FS & -0.38 & -0.38 & -0.16 & -0.87 & -0.65 & 0.73 & 1.00 & & & & & & & & & & & & & & & & & & \\
\hline VFS & 0.83 & 0.83 & 0.82 & 0.70 & 0.86 & -0.61 & -0.36 & 1.00 & & & & & & & & & & & & & & & & & \\
\hline ST & 0.27 & 0.27 & 0.24 & 0.69 & 0.55 & -0.28 & -0.34 & 0.71 & 1.00 & & & & & & & & & & & & & & & & \\
\hline $\mathrm{CL}$ & 0.47 & 0.47 & 0.56 & 0.47 & 0.55 & -0.25 & -0.07 & 0.87 & 0.83 & 1.00 & & & & & & & & & & & & & & & \\
\hline Al & 0.83 & 0.83 & 0.90 & 0.43 & 0.70 & -0.64 & -0.28 & 0.81 & 0.22 & 0.60 & 1.00 & & & & & & & & & & & & & & \\
\hline $\mathrm{Ba}$ & -0.07 & -0.07 & 0.03 & -0.37 & -0.19 & 0.46 & 0.74 & 0.05 & 0.22 & 0.28 & -0.26 & 1.00 & & & & & & & & & & & & & \\
\hline $\mathrm{Ca}$ & 0.63 & 0.63 & 0.47 & 0.56 & 0.56 & -0.36 & -0.54 & 0.72 & 0.40 & 0.55 & 0.70 & -0.37 & 1.00 & & & & & & & & & & & & \\
\hline $\mathrm{Pb}$ & 0.51 & 0.51 & 0.70 & 0.04 & 0.34 & -0.46 & -0.04 & 0.42 & -0.18 & 0.29 & 0.85 & -0.35 & 0.35 & 1.00 & & & & & & & & & & & \\
\hline Co & 0.20 & 0.20 & 0.38 & -0.24 & 0.08 & 0.09 & 0.65 & 0.21 & 0.15 & 0.31 & 0.02 & 0.89 & -0.40 & -0.02 & 1.00 & & & & & & & & & & \\
\hline $\mathrm{Cu}$ & 0.85 & 0.85 & 0.97 & 0.30 & 0.70 & -0.53 & 0.05 & 0.82 & 0.30 & 0.66 & 0.83 & 0.27 & 0.38 & 0.63 & 0.57 & 1.00 & & & & & & & & & \\
\hline $\mathrm{Cr}$ & 0.82 & 0.82 & 0.89 & 0.43 & 0.72 & -0.47 & -0.05 & 0.94 & 0.54 & 0.85 & 0.84 & 0.24 & 0.59 & 0.55 & 0.43 & 0.94 & 1.00 & & & & & & & & \\
\hline $\mathrm{Fe}$ & 0.78 & 0.78 & 0.87 & 0.34 & 0.63 & -0.51 & -0.17 & 0.81 & 0.24 & 0.66 & 0.99 & -0.17 & 0.71 & 0.84 & 0.07 & 0.83 & 0.87 & 1.00 & & & & & & & \\
\hline Mg & 0.66 & 0.66 & 0.72 & 0.33 & 0.55 & -0.65 & -0.38 & 0.54 & -0.07 & 0.29 & 0.91 & -0.58 & 0.59 & 0.93 & -0.26 & 0.58 & 0.55 & 0.87 & 1.00 & & & & & & \\
\hline Mn & -0.42 & -0.42 & -0.25 & -0.74 & -0.56 & 0.48 & 0.80 & -0.59 & -0.49 & -0.44 & -0.53 & 0.63 & -0.89 & -0.23 & 0.65 & -0.11 & -0.35 & -0.51 & -0.53 & 1.00 & & & & & \\
\hline $\mathrm{Hg}$ & -0.30 & -0.30 & -0.38 & -0.25 & -0.44 & 0.61 & 0.12 & -0.06 & 0.04 & 0.15 & -0.05 & -0.08 & 0.48 & -0.10 & -0.45 & -0.33 & -0.08 & 0.07 & -0.06 & -0.38 & 1.00 & & & & \\
\hline $\mathrm{Ni}$ & 0.72 & 0.72 & 0.91 & 0.20 & 0.57 & -0.50 & 0.07 & 0.74 & 0.20 & 0.64 & 0.90 & 0.08 & 0.38 & 0.85 & 0.40 & 0.93 & 0.88 & 0.91 & 0.75 & -0.17 & -0.22 & 1.00 & & & \\
\hline K & 0.54 & 0.54 & 0.63 & 0.21 & 0.41 & -0.55 & -0.32 & 0.41 & -0.19 & 0.19 & 0.85 & -0.62 & 0.53 & 0.94 & -0.32 & 0.49 & 0.44 & 0.81 & 0.99 & -0.48 & 0.00 & 0.70 & 1.00 & & \\
\hline V & 0.75 & 0.75 & 0.71 & 0.47 & 0.64 & -0.30 & -0.15 & 0.92 & 0.62 & 0.84 & 0.72 & 0.21 & 0.79 & 0.31 & 0.23 & 0.75 & 0.91 & 0.78 & 0.41 & -0.54 & 0.24 & 0.65 & 0.30 & 1.00 & \\
\hline $\mathrm{Zn}$ & 0.62 & 0.62 & 0.67 & 0.12 & 0.37 & -0.25 & -0.07 & 0.63 & 0.06 & 0.52 & 0.89 & -0.22 & 0.77 & 0.80 & -0.10 & 0.64 & 0.71 & 0.93 & 0.82 & -0.52 & 0.37 & 0.76 & 0.81 & 0.71 & 1.00 \\
\hline
\end{tabular}

Significant correlations (positive or negative) are marked in bold $(p<0.05)$. 
(a) Projection of the variables on the factor-plane (1 $\times 2$ 2)

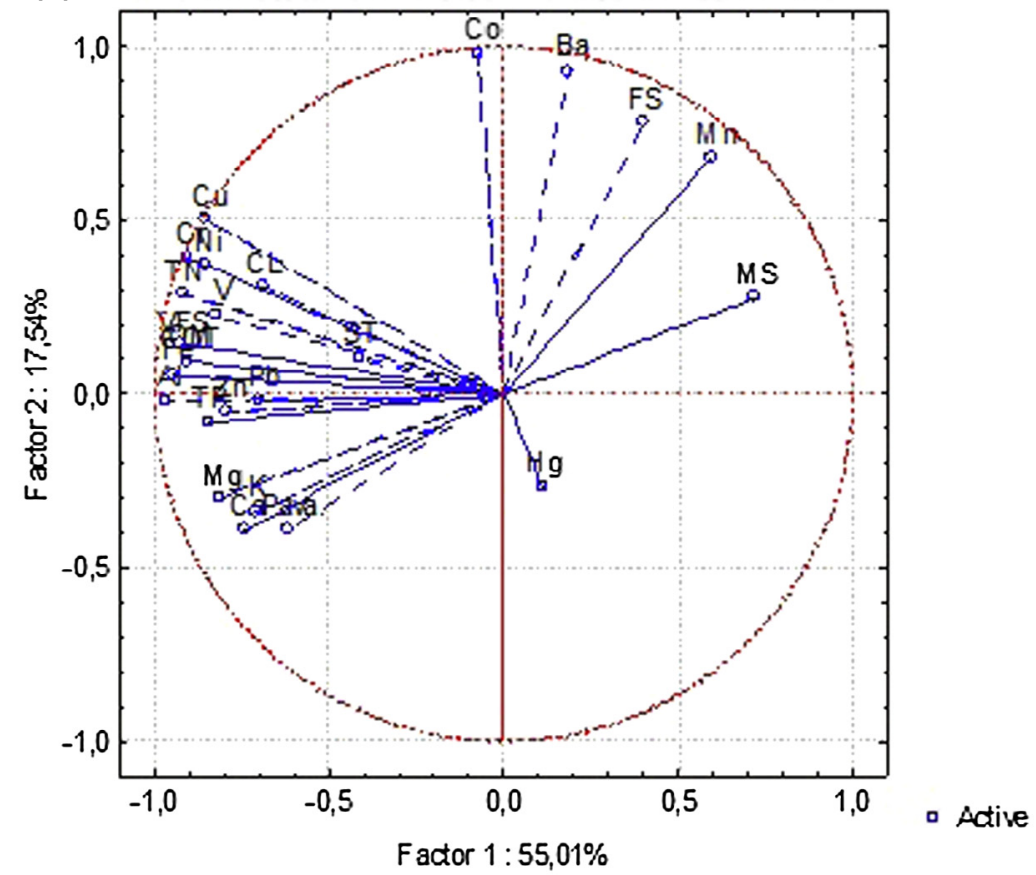

(b) Projection of the cases on the factor-plane $(1 \times 2)$

Cases with sum of cosine square $>=0,00$

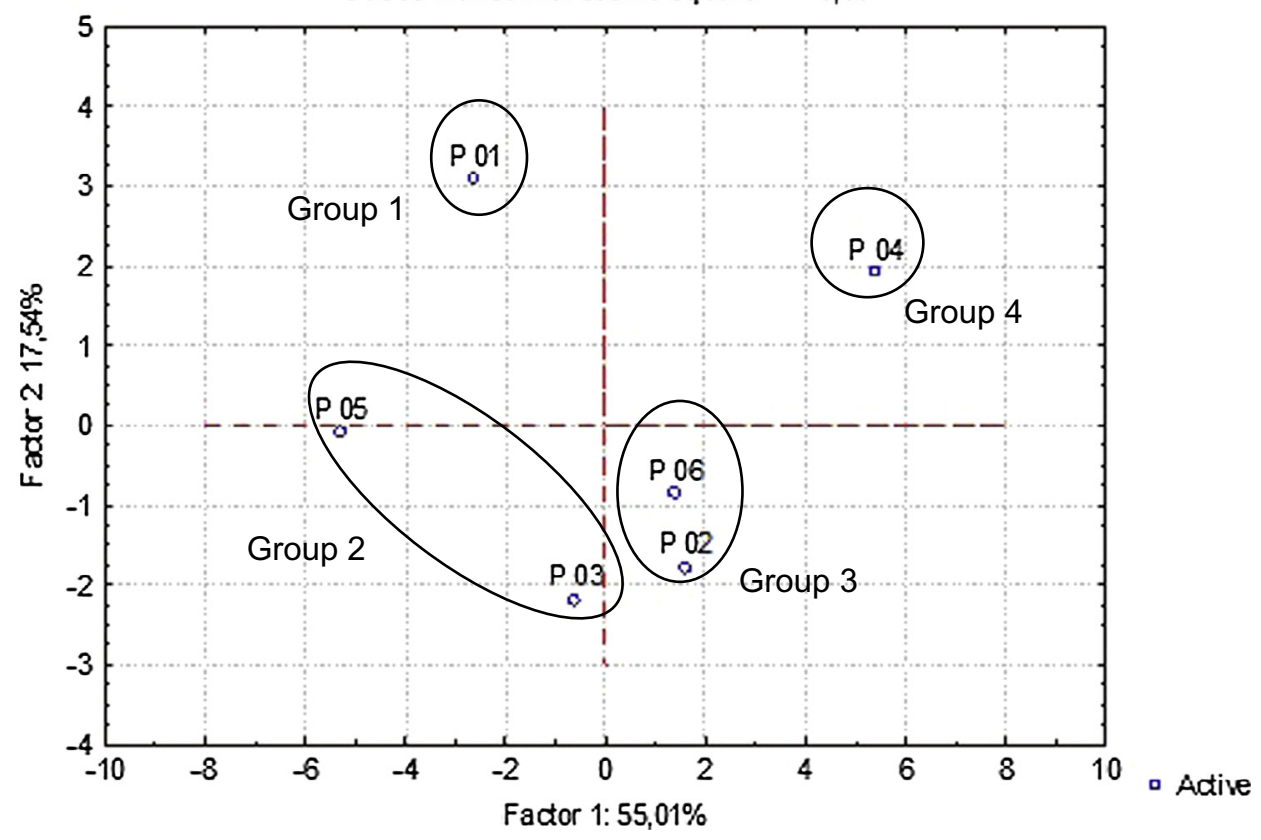

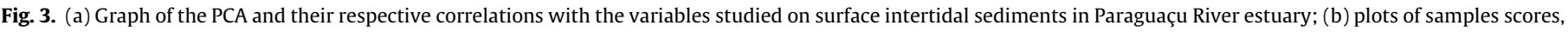
identifying their respective geochemical groups.

possible sign that those metals are sharing a unique source and transport pathway (Mwanamoki et al., 2014). Correlation between different metals can provide information about the sources of contamination and metal pathways (Zahra et al., 2014). The concentrations of $\mathrm{Al}$ and $\mathrm{Fe}$ had significantly high correlation with a great majority of other metals ( $\mathrm{Pb}, \mathrm{Cu}, \mathrm{Cr}, \mathrm{Mg}, \mathrm{Ni}, \mathrm{K}$, and $\mathrm{Zn}$ ). This is a necessary condition for an element become a normalizer according to Matthai and Birch (2001) and also shows that those elements were part of the natural constitution of sediments of the region. In fact, minerals classified as kaolinite $\left(\mathrm{Al}_{2} \mathrm{Si}_{2} \mathrm{O}_{5}(\mathrm{OH})_{4}\right)$ and goethita
$(\mathrm{FeO}(\mathrm{OH}))$ are abundant in the study area (Ramos, 1993). The high positive correlations between $\mathrm{Pb}, \mathrm{Mg}, \mathrm{K}$ and $\mathrm{Zn}$ showed a bigger relationship with the marine water, rich in $\mathrm{Mg}$ and $\mathrm{K}$. This suggests that the enrichment of $\mathrm{Pb}$ and $\mathrm{Zn}$ on Paraguaçu estuary comes from sources inside the Todos os Santos Bay. Mg and K also had a significantly correlation with Fe which highlights another source of these metals: input from lithogenic origin, since they are generally present in the parent rock material (Zahra et al., 2014). High correlations occurred between $\mathrm{Cu}, \mathrm{Cr}$ and $\mathrm{Ni}$, suggesting that those metals have common sources, mutual dependence and identical 
behavior during the transport. The only significant negative correlation regarding metals was between $\mathrm{Ca}$ and $\mathrm{Mn}(-0.89)$, indicating that the enrichment of these metals is not controlled by a single factor (Suresh et al., 2012).

The PCA allows the identification of the components responsible for the full variation of the data even as the groups of variables that explain these variations (Burak et al., 2010). This technique has been extensively used to identify patterns of environmental contamination (Brady et al., 2015; Cho et al., 2015; Yang et al., 2015). The PCA results for nutrients, grain size and metals in the sediments are shown in Fig. 3. The main variables in this study were organic matter, total organic carbon, total nitrogen, very fine sand, $\mathrm{Al}, \mathrm{Ba}, \mathrm{Co}, \mathrm{Cu}, \mathrm{Cr}, \mathrm{Fe}, \mathrm{Mn}$ and $\mathrm{Ni}$. The first two principal components explained a cumulative variance in the data of $72.55 \%$ (PC1: 55.01\%; PC2: 17.54\%) (Table 8). The results indicated that MS had significant positive correlation with the PC1, suggesting that this component represents the influence of that grain size fraction. On the other hand, a set of variables (OM, TOC, TN, TP, VFS, Al, Ca, Cu, Cr, Fe, Mg, Ni, K, V and $\mathrm{Zn}$ ) had significant negative correlation with the PC1. This confirms the tendency of metals to be associated with fine grain size fractions and organic matter compounds (Bayen, 2012). FS, Ba and Co were positively correlated to the second axis. Compared with background values of these metals, the concentration values found in the present study showed relatively low levels of these pollutants in the same area (P 01). This result may be explained by the fact that PC2 mainly represents natural sources. $\mathrm{Hg}$ showed significant correlation neither with the principal components nor with sediment grain-size. The principal component analysis loading plot showed that the elements could be classified into four groups with stronger relationship among its variables. The group 1 , made up by P 01 , contains $\mathrm{Co}$ and $\mathrm{Ba}$, with the first having the best representation on PCA graph. Those metals were significantly positively correlated (0.89) and both have their major concentrations in site P 01. Ba is present in igneous rocks which were found surrounding P 01, and therefore suggesting that the concentration of $\mathrm{Ba}$ on the place have higher natural source. Group 2, made up by P 03 and P 05, had nutrient variables (OM, TOC, TN, $P_{\text {ava }}$ and TP), the finer grain size

Table 8

Two principal components loadings obtained from the PCA.

\begin{tabular}{|c|c|c|}
\hline & Component 1 & Component 2 \\
\hline Variance explained & $55.01 \%$ & $17.54 \%$ \\
\hline $\mathrm{OM}$ & -0.903 & 0.093 \\
\hline TOC & -0.904 & 0.093 \\
\hline $\mathrm{TN}$ & -0.919 & 0.285 \\
\hline$P_{\text {ava }}$ & -0.612 & -0.392 \\
\hline TP & -0.847 & -0.078 \\
\hline MS & 0.719 & 0.276 \\
\hline FS & 0.398 & 0.781 \\
\hline VFS & -0.924 & 0.139 \\
\hline ST & -0.415 & 0.101 \\
\hline $\mathrm{CL}$ & -0.693 & 0.309 \\
\hline $\mathrm{Al}$ & -0.964 & -0.019 \\
\hline $\mathrm{Ba}$ & 0.190 & 0.930 \\
\hline $\mathrm{Ca}$ & -0.744 & -0.391 \\
\hline $\mathrm{Pb}$ & -0.696 & -0.022 \\
\hline Co & -0.072 & 0.977 \\
\hline $\mathrm{Cu}$ & -0.853 & 0.501 \\
\hline $\mathrm{Cr}$ & -0.901 & 0.393 \\
\hline $\mathrm{Fe}$ & -0.943 & 0.056 \\
\hline $\mathrm{Mg}$ & -0.809 & -0.302 \\
\hline Mn & 0.601 & 0.681 \\
\hline $\mathrm{Hg}$ & 0.110 & -0.267 \\
\hline $\mathrm{Ni}$ & -0.851 & 0.369 \\
\hline K & -0.713 & -0.339 \\
\hline V & -0.818 & 0.231 \\
\hline $\mathrm{Zn}$ & -0.794 & -0.048 \\
\hline
\end{tabular}

Loadings above 0.7 market in bold. fractions (very fine sand, silt and clay) and majority of the metals ( $\mathrm{Al}, \mathrm{Ca}, \mathrm{Pb}, \mathrm{Cu}, \mathrm{Cr}, \mathrm{Fe}, \mathrm{Mg}, \mathrm{Ni}, \mathrm{K}, \mathrm{V}$, and $\mathrm{Zn}$ ). The association of this group confirms previous results that show the influence of the $\mathrm{OM}$ content and the finer grain size fractions of the sediments on metal bioavailability (Fernandes et al., 2011; Mwanamoki et al., 2014; Zahra et al., 2014). The group 3, made up by P 02 and P 06, contains $\mathrm{Hg}$, which did not have a good representation on PCA graph, and was far from the other studied parameters. In both sampling stations the highest $\mathrm{Hg}$ concentrations happened in which the levels were higher than the background values. Group 4, made up by $\mathrm{P}$ 04, consists of medium sand, fine sand, and manganese. Mn had its biggest correlation value with fine sand (0.8) and it is close to this parameter on the PCA graph. Mn bioavailability has been related to fine sand fraction (Fernandes and Nayak, 2014). Besides, the anthropogenic inputs of this metal in P 04 were already highlighted by $\mathrm{EF}, I_{\text {geo }}$ and $\mathrm{PI}_{\mathrm{N}}$.

\section{Conclusions}

Statistical analyses ratified the correlation between the bioavailability of metals, concentration of organic matter on sediment, and finer size grains. On Paraguaçu Estuary the majority of the metals showed enrichment relatively to the background values of the area, even though they had average concentrations lower than UET, ERL, ERM, TEL and PEL from NOAA, except for Hg that had concentration higher than TEL and ERL on P 06, confirming previous $\mathrm{Hg}$ contamination on Todos os Santos Bay. The $I_{\text {geo }}$ and $\mathrm{PI}_{\mathrm{N}}$ indices seemed to be more sensitive than EF for the study of the pollutants in the area, showing a further metal enrichment in this environment. EF and $I_{\text {geo }}$ indicated severe enrichment of $\mathrm{Mn}$ on $\mathrm{P}$ 04. The results of $\mathrm{PI}_{\mathrm{N}}$, showed moderated contamination for P 01, P 02, P 03, P 05 and P 06. According to $\mathrm{PI}_{\mathrm{N}}$ values, P 04 had a strong pollution because of the $\mathrm{Mn}$, showing that this metal has a high anthropogenic input in this site, mainly, due to the shipbuilding and petroleum industrial activities. Suggestions for future studies of the area are: a monitoring system with higher number of samples and seasonal variability; mineral analyses of sediments; isotopic analyses to identify metals origin and study of the benthic organisms, especially focusing on bioaccumulation of the metals on local biota.

\section{References}

Abrahim, G.M.S., Parker, R.J., 2008. Assessment of heavy metal enrichment factors and the degree of contamination in marine sediments from Tamaki Estuary, Auckland, New Zealand. Environ. Monit. Assess. 136, 227-238.

Al-Ghais, S.M., 2013. Acetylcholinesterase, glutathione and hepatosomatic index as potential biomarkers of sewage pollution and depuration in fish. Mar. Pollut. Bull. 74, 183-186.

Armid, A., Shinjob, R., Zaenia, A., Sanic, A., Ruslan, R., 2014. The distribution of heavy metals including $\mathrm{Pb}, \mathrm{Cd}$ and $\mathrm{Cr}$ in Kendari Bay surficial sediments. Mar. Pollut. Bull. 84, 373-378.

Aspila, K.I., Agemian, H., Chau, A.S.Y., 1976. A semi-automated method for the determination of inorganic, organic and total phosphate in sediments. Analyst $101,187-197$

Barros, F., Hatje, V., Figueredo, M.B., Magalhães, W.F., Dórea, H.S., Emídio, E.S., 2008. The structure of the benthic macrofaunal assemblages and sediments characteristics of the Paraguaçu estuarine system, NE, Brazil. Estuar. Coast. Shelf Sci. 78, 753-762.

Bastami, K.D., Neyestani, M.R., Shemirani, F., Soltani, F., Haghparast, S., Akbari, A., 2015. Heavy metal pollution assessment in relation to sediment properties in the coastal sediments of the southern Caspian Sea. Mar. Pollut. Bull. 92, 237243.

Bayen, S., 2012. Occurrence, bioavailability and toxic effects of trace metals and organic contaminants in mangrove ecosystems: a review. Environ. Int. 48, 84101.

Boaventura, S.F., 2011. Distribuição de metais traço em superfície no município de Madre de Deus, Bahia. Dissertação (Mestrado em Geoquímica: Petróleo e Meio Ambiente). Instituto de Geociências, Universidade Federal da Bahia.

Brady, J.P., Ayoko, G.A., Martens, W.N., Goonetilleke, A., 2014. Enrichment, distribution and sources of heavy metals in the sediments of Deception Bay, Queensland, Australia. Mar. Pollut. Bull. 81, 248-255. 
Brady, J.P., Ayoko, G.A., Martens, W.N., Goonetilleke, A., 2015. Weak acid extractable metals in Bramble Bay, Queensland, Australia: temporal behaviour, enrichment and source apportionment. Mar. Pollut. Bull. 91, 380-388.

Burak, D.L., Fontes, M.P.F., Santos, N.T., Monteirod, L.V.S., Martins, E.S., Becquer, T., 2010. Geochemistry and spatial distribution of heavy metals in Oxisols in a mineralized region of the Brazilian Central Plateau. Geoderma 160, 131-142.

Camargo, J.B.D.A., Cruz, A.C.F., Campos, B.G., Araújo, G.S., Fonseca, T.G., Abessa, D.M.S., 2015. Use, development and improvements in the protocol of wholesediment toxicity identification evaluation using benthic copepods. Mar. Pollut. Bull. 91, 511-517.

Chakraborty, P., Ramteke, D., Chakraborty, S., Nath, B.N., 2014. Changes in metal contamination levels in estuarine sediments around India - an assessment. Mar. Pollut. Bull. 78, 15-25.

Chapman, P.M., 2002. Integrating toxicology and ecology: putting the "eco" into ecotoxicology. Mar. Pollut. Bull. 44, 7-15.

Cheng, J.-L., Shi, Z., Zhu, Y.-W., 2007. Assessment and mapping of environmental quality in agricultural soils of Zhejiang Province, China. J. Environ. Sci. 19, 5054.

Cho, J., Hyun, S., Han, J.-H., Kim, S., Shin, D.-H., 2015. Historical trend in heavy metal pollution in core sediments from the Masan Bay, Korea. Mar. Pollut. Bull. 95, 427-432.

Couillard, Y., Grapentine, L.C., Borgmann, U., Doyle, P., Masson, S., 2008. The amphipod Hyalella azteca as a biomonitor in field deployment studies for metal mining. Environ. Pollut. 156, 1314-1324.

CRA, 2004. Diagnóstico da concentração de metais pesados e hidrocarbonetos de petróleo nos sedimentos e biota da Baía de Todos os Santos. Consórcio BTS Hydros CH2MHILL. Governo do Estado da Bahia.

Duman, F., Aksoy, A., Demirezen, D., 2007. Seasonal variability of heavy metals in surface sediment of Lake Sapanca, Turkey. Environ. Monit. Assess. 133, $277-$ 283

EMBRAPA. Centro Nacional de Pesquisa de Solos, 2009. Manual de métodos análises químicas para avaliação de fertilidade do solo, second ed. Embrapa Informações Tecnológicas, Brasília, Brazil, 627 p.

EIA - ESTUDO DE IMPACTO AMBIENTAL, Estaleiro do Paraguaçu, 2009. Salvador.

Fernandes, L., Nayak, G.N., 2014. Characterizing metal levels and their speciation in intertidal sediments along Mumbai coast, India. Mar. Pollut. Bull. 79, 371-378.

Fernandes, L., Nayak, G.N., Ilangovan, D., Borole, D.V., 2011. Accumulation of sediment, organic matter and trace metals with space and time, in a creek along Mumbai coast, India. Estuar. Coast. Shelf Sci. 91, 388-399.

Fernández-Cadena, J.C., Andrade, S., Silva-Coello, C.L., De la Iglesia, R., 2014. Heavy metal concentration in mangrove surface sediments from the north-west coast of South America. Mar. Pollut. Bull. 82, 221-226.

Folk, R.L., Ward, W.C., 1957. Brazos river bar: a study of significance of grain size parameters. J. Sediment. Petrol. 27, 3-26.

Gao, X., Zhou, F., Chen, C.A., 2014. Pollution status of the Bohai Sea: an overview of the environmental quality assessment related trace metals. Environ. Int. 62, 12 30.

Garcia, K.S., Anunciação, D.S., Jesus, G.M., Gomes, J.M.P., Soares, S.A.R., Garcia, R.J.L., 2014. Técnicas de campo e laboratório aplicadas às matrizes dos ambientes costeiros nos municípios de Una, Canavieiras e Belmonte. In: Celino, J. J., Hadlich, G.M., Queiroz, A.F.S., Oliveira, O.M.C. (Org. (s)). Avaliação de ambientes costeiros da região Sul da Bahia, geoquímica, petróleo e sociedade. Edufba, Salvador, Brazil, p. 37-61.

Hakanson, L., 1980. Ecological risk index for aquatic pollution control, a sedimentological approach. Water Res. 14, 975-1001.

Hamdoun, H., Van-Veen, E., Basset, B., Lemoine, M., Coggan, J., Leleyter, L., Baraud, F., 2015. Characterization of harbor sediments from the English Channel: assessment of heavy metal enrichment, biological effect and mobility. Mar. Pollut. Bull. 90, 273-280.

Hatje, V., Bícego, M.C., Carvalho, G.C., Andrade, J.B., 2009. Contaminação química. In: Hatje, V., Andrade, J.B. (Org. (s)). Baía de Todos os Santos: aspectos oceanográficos. Edufba, Salvador, Brazil, p. 243-297.

Hoff, N.T., Figueira, R.C.L., Abessa, D.M.S., 2014. Levels of metals, arsenic and phosphorus in sediments from two sectors of a Brazilian Marine Protected Area (Tupinambás Ecological Station). Mar. Pollut. Bull. 91, 403-409.

Jiang, X., Teng, A., Xu, W., Liu, X., 2014. Distribution and pollution assessment of heavy metals in surface sediments in the Yellow Sea. Mar. Pollut. Bull. 83, 366375.

Jin, X., Liu, F., Wang, Y., Zhang, L., Li, Z., Wang, Z., Giesy, J.P., Wang, Z., 2015. Probabilistic ecological risk assessment of copper in Chinese offshore marine environments from 2005 to 2012. Mar. Pollut. Bull. 94, 96-102.

Lessa, G., Dias, K., 2009. Distribuição espacial das litofácies de fundo da Baía de Todos os Santos. Quat. Environ. Geosci. 1, 84-97.

Lin, Y.-C., Chang-Chien, G.-P., Chiang, P.-C., Chen, W.-H., Lin, Y.-C., 2013. Multivariate analysis of heavy metal contaminations in seawater and sediments from a heavily industrialized harbor in Southern Taiwan. Mar. Pollut. Bull. 76, 266-275.

Magesh, N.S., Chandrasekar, N., Kumar, S.K., Glory, M., 2013. Trace element contamination in the estuarine sediments along Tuticorin coast - Gulf of Mannar, southeast coast of India. Mar. Pollut. Bull. 73, 355-361.

Marins, R.V., Filho, F.J.P., Maia, S.R.R., 2004. Distribuição de mercúrio total como indicador de poluição urbana e industrial na costa brasileira. Quím. Nova 27, $763-770$.

Matthai, C., Birch, G., 2001. Detection of anthropogenic Cu, Pb and $\mathrm{Zn}$ in continental shelf sediments off Sydney, Australia - a new approach using normalization with Cobalt. Mar. Pollut. Bull. 42, 1055-1063.
Merhaby, D., Net, S., Halwani, J., Ouddane, B., 2015. Organic pollution in surficial sediments of Tripoli harbour, Lebanon. Mar. Pollut. Bull. 93, 284-293.

Mestrinho, S.S.P., 1998. Estudo do comportamento geoquímico dos metais pesados nos sedimentos da região estuarina do rio Paraguaçu - Bahia. Tese (Doutorado em Recursos Minerais e Hidrologia). Instituto de Geociências, Universidade de São Paulo.

Moldanová, J., Fridell, E., Popovicheva, O., Demirdjian, B., Tishkova, V., Faccinetto, A. Focsa, C., 2009. Characterisation of particulate matter and gaseous emissions from a large ship diesel engine. Atmos. Environ. 43, 2632-2641.

Moreira, I.T.A., Oliveira, O.M.C., Triguis, J.A., Queiroz, A.F.S., Barbosa, R.M., Anjos J.A.S.A., Reyes, C.Y., Silva, C.S., Trindade, M.C.L.F., Rios, M.C., 2013. Evaluation of the effects of metals on biodegradation of total petroleum hydrocarbons. Microchem. J. 110, 215-220.

Müller, G., 1979. Schwermetalle in den Sedimenten des Rheins-Veränderungen seit 1971. Umschau 79, 778-783.

Mwanamoki, P.M., Devarajan, N., Thevenon, F., Birane, N., de Alencastro, L.F., Grandjean, D., Mpiana, P.T., Prabakar, K., Mubedi, J.I., Kabele, C.G., Wildi, W., Poté, J., 2014. Trace metals and persistent organic pollutants in sediments from river-reservoir systems in Democratic Republic of Congo (DRC): spatial distribution and potential ecotoxicological effects. Chemosphere 111, 485-492.

Naser, H.A., 2013. Assessment and management of heavy metal pollution in the marine environment of the Arabian Gulf: a review. Mar. Pollut. Bull. 72, 6-13.

Otero, O.M.F., Barbosa, R.M., Queiroz, A.F.S., Castro, A.M., Macêdo, B.L.F., 2008 Valores de referência para metais traço nos sedimentos de manguezais da Baía de Todos os Santos. In: Queiroz, A.F., Celino, J.J. (Org. (s)). Avaliação de ambientes na Baía de Todos os Santos: aspectos geoquímicos, geofísicos e biológicos. Edufba, Salvador, Brazil, p. 39-58.

de Paula Filho, F.J., Marins, R.V., Lacerda, L.D., Aguiar, J.E., Peres, T.F., 2015 Background values for evaluation of heavy metal contamination in sediments in the Parnaíba River Delta estuary, NE/Brazil. Mar. Pollut. Bull. 91, 424-428.

Peña-Icart, M., Mendiguchía, C., Villanueva-Tagle, M.E., Pomares-Alfonso, M.S. Moreno, C., 2014. Revisiting methods for the determination of bioavailable metals in coastal sediments. Mar. Pollut. Bull. 89, 67-74.

Ramos, M.A.B., 1993. Estudos geoquímicos relativamente à dinâmica de marés no estuário lagunar do rio Paraguaçu - Bahia - Brasil. Dissertação (Mestrado em Geociências). Instituto de Geociências, Universidade Federal da Bahia.

Reis, P.A., Salgado, M.A., Vasconcelos, V., 2013. Seasonal variation of metal contamination in the barnacles Pollicipes pollicipes in northwest coast of Portugal show clear correlation with levels in the surrounding water. Mar Pollut. Bull. 70, 155-161.

RIMA - Relatório de Impacto ao Meio Ambiente, Estaleiro do Paraguaçu, 2009 Salvador.

Qingjie, G., Jun, D., Yunchuan, X., Qingfei, W., Liqiang, Y., 2008. Calculating pollution indices by heavy metals in ecological geochemistry assessment and a case study in parks of Beijing. J. China Univ. Geosci. 19, 230-241.

Santos, C., 2007. Estatística descritiva - Manual de auto-aprendizagem,, Edições Silabo, Lisboa.

Serna, A., Lahajnara, N., Pätschc, J., Hebbelnd, D., Emeis, K., 2014. Organic matter degradation in the German Bight/SE North Sea: implications from stable nitrogen isotopes and amino acids. Mar. Chem. 166, 103-113.

Song, Y., Choi, M.S., Lee, J.Y., Jang, D.J., 2014. Regional background concentrations of heavy metals ( $\mathrm{Cr} \mathrm{Co}, \mathrm{Ni}, \mathrm{Cu}, \mathrm{Zn}, \mathrm{Pb}$ ) in coastal sediments of the South Sea of Korea. Sci. Total Environ. 482-483, 80-91.

Souza, I.daC., Rocha, L.D., Morozesk, M., Bonomo, M.M., Arrivabene, H.P., Duarte, I.D., Furlan, L.M., Monferrán, M.V., Mazik, K., Elliott, M., Matsumoto, S.T., Milanez C.R.D., Wunderlin, D.A., Fernandes, M.N., 2015. Changes in bioaccumulation and translocation patterns between root and leafs of Avicennia schaueriana as adaptive response to different levels of metals in mangrove system. Mar. Pollut. Bull. 94, 176-184.

Suresh, G., Sutharsan, P., Ramasamy, V., Venkatachalapathy, R., 2012. Assessment of spatial distribution and potential ecological risk of the heavy metals in relation to granulometric contents of Veeranam lake sediments, India. Ecotoxicol. Environ. Safe. 84, 117-124.

Taylor, K.G., Boult, S., 2007. The role of grain dissolution and diagenetic mineral precipitation in the cycling of metals and phosphorus: a study of a contaminated urban freshwater sediment. Appl. Geochem. 22, 1344-1358.

Veerasingam, S., Vethamony, P., Murali, R.M., Fernandes, B., 2015. Depositional record of trace metals and degree of contamination in core sediments from the Mandovi estuarine mangrove ecosystem, west coast of India. Mar. Pollut. Bull. 91, 362-367.

Velusamy, A., Kumar, P.S., Ram, A., Chinnadurai, S., 2014. Bioaccumulation of heavy metals in commercially important marine fishes from Mumbai Harbor, India. Mar. Pollut. Bull. 81, 218-224.

Walker, G.M., Hanna, J.-A., Allen, S.J., 2005. Treatment of hazardous shipyard wastewater using dolomitic sorbents. Water Res. 39, 2422-2428.

Wang, H., Wang, J., Liu, R., Yu, W., Shen, Z., 2015. Spatial variation, environmental risk and biological hazard assessment of heavy metals in surface sediments of the Yangtze River estuary. Mar. Pollut. Bull. 93, 250-258.

Wei, Z., Wang, D., Zhou, H., Qi, Z., 2011. Assessment of soil heavy metal pollution with principal component analysis and geoaccumulation index. Procedia Environ. Sci. 10, 1946-1952.

Wu, G., Shang, J., Pan, L., Wang, Z., 2014. Heavy metals in surface sediments from nine estuaries along the coast of Bohai Bay, Northern China. Mar. Pollut. Bull. 82, 194-200.

Yamamoto, T., 2003. The Seto Inland Sea--eutrophic or oligotrophic? Mar. Pollut Bull. 47, 37-42. 
Yang, X., Yuan, X., Zhang, A., Mao, Y., Li, Q., Zong, H., Wang, L., Li, X., 2015. Spatial distribution and sources of heavy metals and petroleum hydrocarbon in the sand flats of Shuangtaizi Estuary, Bohai Sea of China. Mar. Pollut. Bull. 95, 503-512.

Yu, X., Li, H., Pan, K., Yan, Y. Wang, W., 2012. Mercury distribution, speciation an bioavailability in sediments from the Pearl River Estuary, Southern China. Mar. Pollut. Bull. 64, 1699-1704.
Zahra, A., Hashmi, M.Z., Malik, R.N., Ahmed, Z., 2014. Enrichment and geoaccumulation of heavy metals and risk assessment of sediments of the Kurang Nallah-feeding tributary of the Rawal Lake Reservoir, Pakistan. Sci. Total Environ. 470-471, 925-933.

Zhao, H., Li, X., 2013. Risk assessment of metals in road-deposited sediment along an urban-rural gradient. Environ. Pollut. 174, 279-304. 